\title{
The Ligands for Human IgG and Their Effector Functions
}

\author{
Steven W. de Taeye ${ }^{1,2, *}$, Theo Rispens ${ }^{1}$ and Gestur Vidarsson ${ }^{2}$ (i) \\ 1 Sanquin Research, Dept Immunopathology and Landsteiner Laboratory, Amsterdam UMC, \\ University of Amsterdam, 1066 CX Amsterdam, The Netherlands; t.rispens@sanquin.nl \\ 2 Sanquin Research, Dept Experimental Immunohematology and Landsteiner Laboratory, Amsterdam UMC, \\ University of Amsterdam, 1066 CX Amsterdam, The Netherlands; g.vidarsson@sanquin.nl \\ * Correspondence: s.detaeye@sanquin.nl
}

Received: 26 March 2019; Accepted: 18 April 2019; Published: 25 April 2019

check for updates

\begin{abstract}
Activation of the humoral immune system is initiated when antibodies recognize an antigen and trigger effector functions through the interaction with $F_{c}$ engaging molecules. The most abundant immunoglobulin isotype in serum is Immunoglobulin $\mathrm{G}(\mathrm{IgG})$, which is involved in many humoral immune responses, strongly interacting with effector molecules. The IgG subclass, allotype, and glycosylation pattern, among other factors, determine the interaction strength of the IgG-Fc domain with these Fc engaging molecules, and thereby the potential strength of their effector potential. The molecules responsible for the effector phase include the classical IgG-Fc receptors (Fc $\gamma \mathrm{R})$, the neonatal Fc-receptor (FcRn), the Tripartite motif-containing protein 21 (TRIM21), the first component of the classical complement cascade (C1), and possibly, the Fc-receptor-like receptors (FcRL4/5). Here we provide an overview of the interactions of $\operatorname{IgG}$ with effector molecules and discuss how natural variation on the antibody and effector molecule side shapes the biological activities of antibodies. The increasing knowledge on the Fc-mediated effector functions of antibodies drives the development of better therapeutic antibodies for cancer immunotherapy or treatment of autoimmune diseases.
\end{abstract}

Keywords: Antibodies; IgG; Fc effector molecules; allotypes; glycosylation

\section{Introduction}

The human adaptive humoral immune system is dependent on antigen recognition via the B cell receptor on naïve $B$ cells, which initiates $B$ cell maturation and eventually production of antibodies by plasmablasts and plasma cells. IgM is the initial antibody class that is made when naïve B cells are activated and can be found as a membrane-bound B cell receptor (BCR) on naïve $B$ cells together with IgD. Like all immunoglobulins, the basic secreted unit is a dimer of two identical heavy chains, each coupled to identical light chains. For IgM, five such units associate together with a Joining (J) chain forming a pentamer, which is a strong activator of the classical complement pathway [1]. Class switching from the initial IgM isotype allows the humoral immune system to engage with each antigen in a specific manner, with unique effector mechanisms being imprinted by each class (IgM, IgG, IgA, IgE, and IgD). Additionally, IgA and IgG are further subdivided in two and four subclasses, respectively (IgA1-2 and IgG1-4). Although the IgA subclasses seem to have similar if not identical effector functions, the abundance at different locations (serum/mucosa) is very different. The effector functions of IgG subclasses are very different and will be a major topic of this review.

During the onset of initial class switching in a given B cell any class switching event is theoretically possible from IgM to any other isotype. However, further sequential class switching events are dependent on the order of the Ig heavy chain constant genes on chromosome 14 (IgM, IgD, IgG3, IgG1, $\operatorname{IgA1}, \operatorname{IgG2}$ IgG4, IgE, and IgA2) [2]. This is because of genetic excisions of constant regions, e.g., the 
exons encoding for IgM, IgD, and IgG3 constant regions are deleted after a class switch event from IgM to IgG1, preventing descendants of the proliferating B cell from generating IgG3. These class switching events of naïve B cells in the germinal center during clonal expansion are not completely random, but are regulated through signals received from T-helper cells and antigen presenting cells (APC). Cytokines produced by T-helper cells and signaling via toll-like receptors (TLR) on B cells initiate class switching of antigen specific B cells via activation-induced deaminase (AID) activity [3].

All the immunoglobulin isotypes have their own biodistribution, function and are often elicited upon specific triggers. $\operatorname{IgD}$, for example, may be found in a secreted form, mostly in the tonsils, but its function remains enigmatic $[4,5]$. IgE is known to interact with mast cells to trigger the release of histamine mostly through the high affinity IgE-Fc Receptor I (Fc\&RI), but it also interacts with the atypical FceRII (CD23), a c-type lectin. IgA has differential function depending on whether it is secretory IgA (SIgA) or serum IgA. SIgA is a dimeric form containing the J-chain (also found in IgM) that is associated with the extracellular domain of the polymeric Ig-Receptor (pIgR), which cleaves off after the transcytosis of dimeric IgA by the pIgR on epithelial cell of the mucosa [6]. Only serum $\operatorname{IgA}$, which is monomeric and not associated with the J-chain, can bind and activate the myeloid IgA-receptor Fc $\alpha$ RI efficiently and trigger a strong cellular response [7-9]. These isotypes-IgA, IgE, and IgD—generally do not activate complement, and therefore rely on other mechanisms to carry out their function $[5,10,11]$. Thus detailed discussion of these isotypes is beyond the scope of this chapter where we will focus on the biology of IgG subclasses.

\section{Immunoglobulin $\mathrm{G}(\mathrm{IgG})$}

In the majority of humoral antibody responses, whether it is the protection against viral or cellular pathogens, IgG-mediated effector functions are involved. This includes humoral responses in allo- or autoimmune diseases. IgG1 is the most abundant antibody in human sera, followed by IgG2, IgG3, and IgG4 respectively [12]. Although the IgG subclasses are more than $90 \%$ identical on the amino acid level, each IgG subclass has a unique profile with respect to structure, antigen binding, immune complex formation, complement activation, triggering of Fc $\gamma \mathrm{R}$, half-life, and placental transport [12] (Figure 1). IgG1, IgG3, and to some extent, IgG4 are generally formed against protein antigens, while IgG2 is the major subclass formed against repetitive $\mathrm{T}$ cell-independent polysaccharide structures found on encapsulated bacteria [13]. IgG3 is often the first subclass to form, which is followed by IgG1 responses that later dominate. The development of IgG4 responses is often the outcome of repeated or prolonged antigen exposure, although class switching from IgM expressing naïve B cells to IgG4 is possible [14]. The unusually weak $\mathrm{CH} 3-\mathrm{CH} 3$ interactions in the Fc domain of IgG4 and the redox sensitive disulfide bonds in the hinge of IgG4 facilitate exchange of two half-molecules (each consisting of one heavy and one light chain from a single IgG4 molecule), which enables the formation of bispecific IgG4 molecules [14-16]. For IgG2, two isoforms (IgG2 A/B) exist as a result of different disulfide bonding in the Fab and hinge domain, which determines the rigidity of the Fab domains when engaging antigen [17]. Functionally, IgG1 and IgG3 are strong inducers of Fc-mediated effector mechanisms, such as antibody-dependent cellular cytotoxicity (ADCC), complement dependent cytotoxicity (CDC), and antibody-dependent cellular phagocytosis (ADCP). IgG2 and IgG4, on the other hand, generally induce more subtle responses, although IgG2 has been shown to be quite capable of inducing good complement and Fc-receptor-mediated responses against epitopes of high-density such as polysaccharides $[18,19]$. This capacity of IgG2 may be related also to the peculiar rigidity of the hinge, shown to result in super agonistic antibodies and triggering strong signaling when targeting immune costimulatory receptors such as CD40 [20]. Below, the interaction of different ligands with human IgG subclasses is discussed as well as the effector functions triggered via these interactions. 


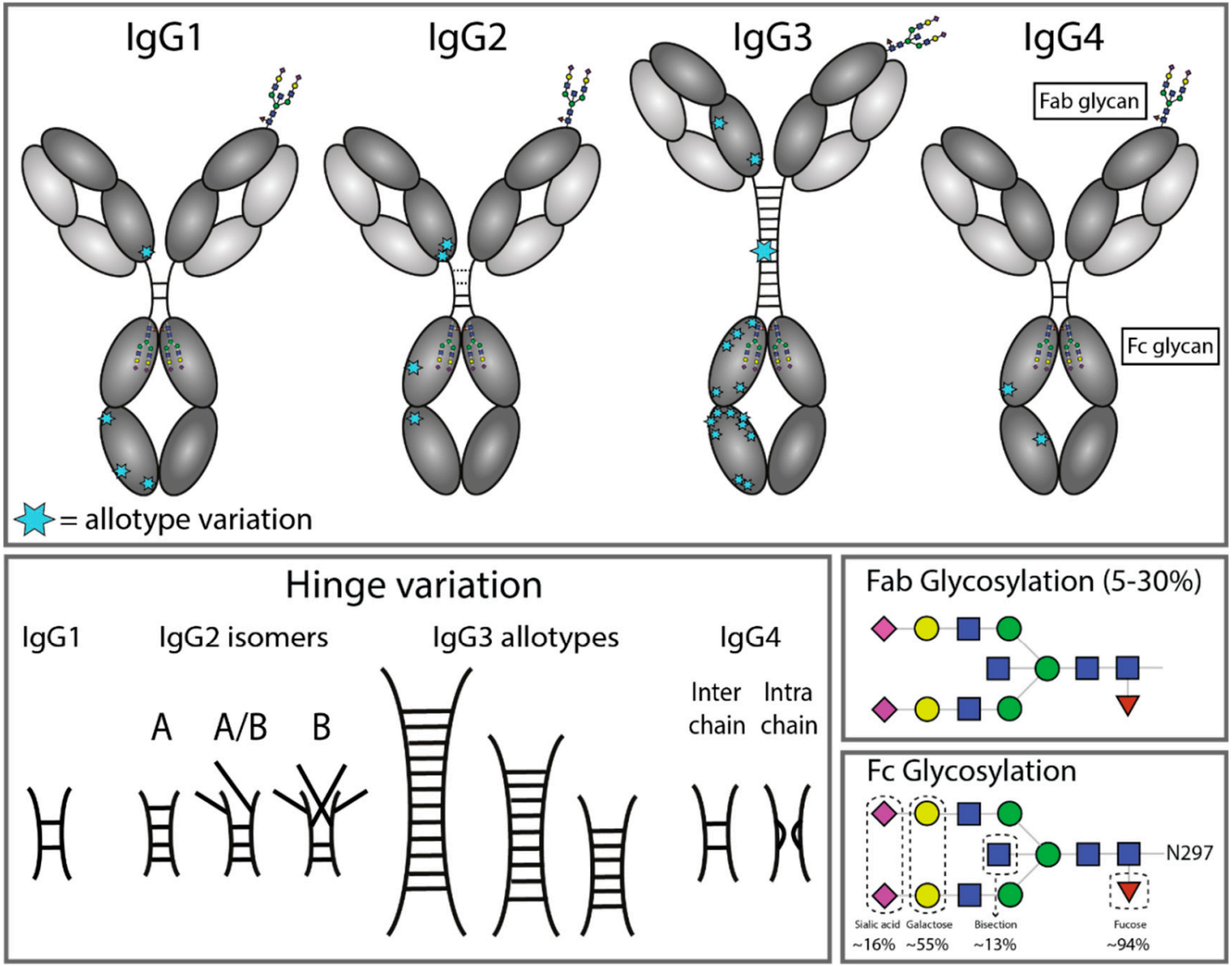

Figure 1. Structural variation of immunoglobulin $G$ subclasses. A structural representation of the immunoglobulin $\mathrm{G}(\mathrm{IgG})$ subclasses and the variation within these subclasses, including allotype variation, hinge variation, and glycosylation. The variation originating from allotypic polymorphisms in the immunoglobulin heavy gamma (IGHG) constant domain is indicated by blue stars. Except for the star representing the variation in hinge length between IgG3 allotypes, each blue star indicates amino acid variation at one particular residue in the constant domain. Fab glycosylation is indicated and is present in 5-30\% of antibodies in serum, depending on subclass and antigen specificity. The glycoform of the N297 Fc glycan is highly variable, for which the frequency of each glycan moiety on IgG antibodies in human serum is indicated.

\section{IgG-Fc-Engaging Effector Molecules}

The Fc domain of antibodies is the target for many proteins, including receptors on myeloid cells and thereby serves as a ligand for adaptor molecules (Figure 2). Many biological activities of antibodies are dependent on the interaction with these effector molecules, comprising Fc gamma receptors $\left(F_{c} \gamma R\right)$ [21], two members of the Fc receptor-Like (FcRL) family (FcRL4 and FcRL5) [22], complement components (C1q) [23], neonatal Fc receptor (FcRn) [24], and Tripartite motif-containing protein 21 (TRIM21) [25]. 


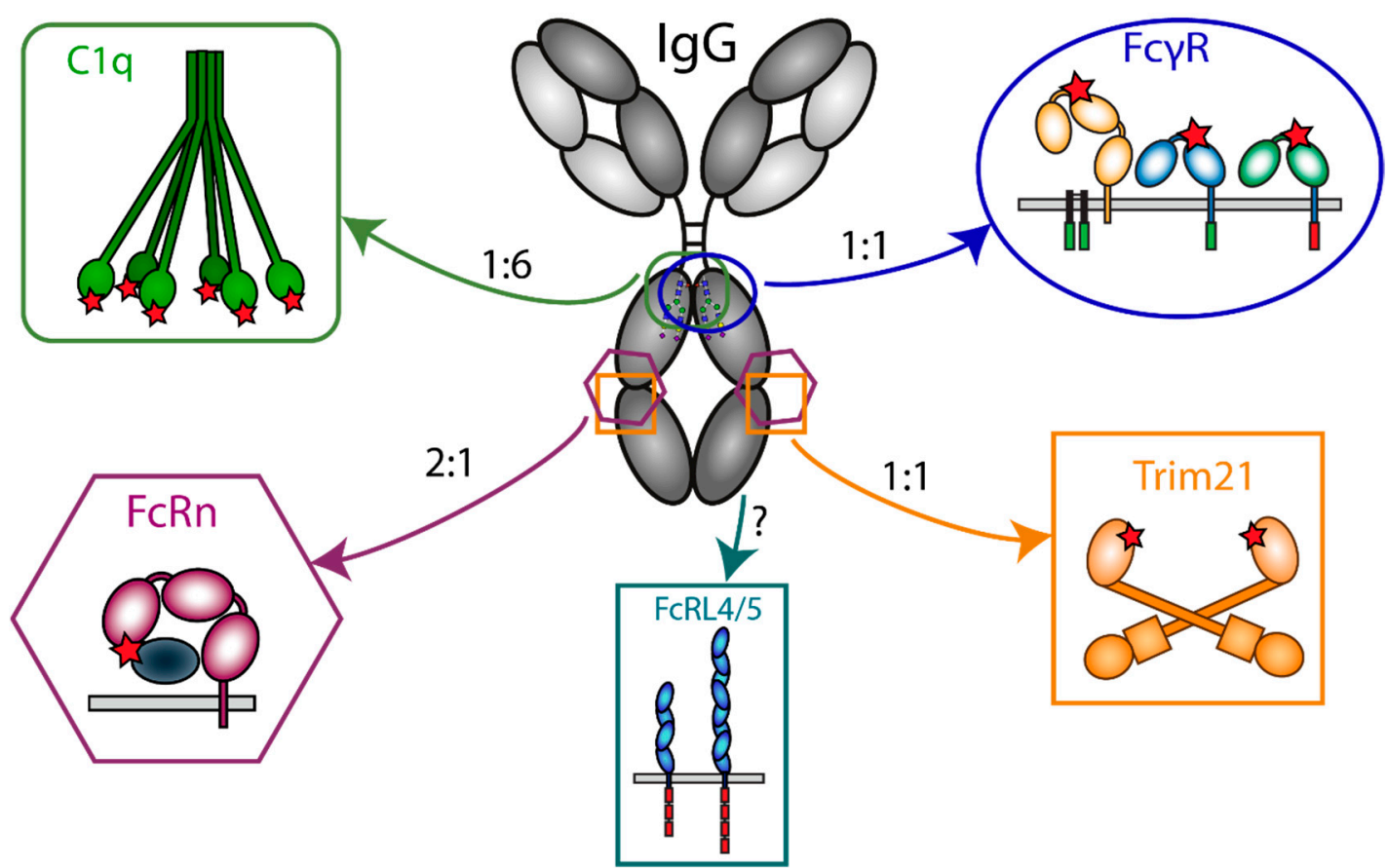

Figure 2. Interaction of IgG with Fc effector molecules. Schematic representation of IgG- and all Fc-engaging molecules (Complement component (C1q), Fc gamma receptors ( $\mathrm{Fc} \gamma \mathrm{R})$, the Neonatal Fc receptor (FcRn), Tripartite motif 21 (Trim21), and Fc receptor-like (FcRL) molecules 4 and 5) through which antibodies exert their biological activity. For each ligand the binding site on IgG and the stoichiometry of the interaction with IgG is indicated. The red stars represent the binding site of $\operatorname{IgG}$ on the Fc effector molecules.

\subsection{Fc-Receptors}

Human myeloid, NK, and some lymphoid cells express Fc gamma receptors (Fc $\gamma \mathrm{R})$, which sense antibody-opsonized particles and exert their specific effector mechanisms upon recognition and clustering of the Fc receptors [26]. Based on monovalent IgG:Fc $\gamma \mathrm{R}$ binding studies, Fc $\gamma \mathrm{R}$ were classified into high-affinity (Fc $\gamma$ RIa) and low-affinity (Fc $\gamma$ RIIa, IIb, IIc, IIIa, and IIIb) receptors [27]. This classification is somewhat of an oversimplification, as, for example, the affinity of IgG1 to Fc $\gamma$ RIIIa can approach that of Fc $\gamma$ RI depending of fucosylation in the IgG1-Fc (see below). These affinities also are not always indicative of their differential functionalities as it is the cross-linking of these Fc-receptors, brought about by engagement with immune complexes or opsonized pathogens with multiple IgG molecules, which enables the initiation of signaling. [28,29].

Most Fc $\gamma R$ associate with an intracellular immunoreceptor tyrosine-based activation motif (ITAM), which is either directly found in the cytoplasmic domain (Fc $\gamma$ RIIa and Fc $\gamma$ RIIc-ORF) or through the associated FcR $\gamma$-chain (Fc $\gamma$ RIa and Fc $\gamma$ RIIIa). The exceptions are Fc $\gamma$ RIIIb, which is GPI-linked, and Fc $\gamma$ RIIb, which has an immunoreceptor tyrosine-based inhibition motif (ITIM). The latter is therefore the only receptor with inhibitory activity, and the only Fc receptor expressed on B cells [30]. The ratio of activating and inhibitory (A:I) Fc $\gamma$ R expression on immune cells is thought to determine the antibody threshold necessary to activate the effector cell and induce ADCC or ADCP [31]. The Fc $\gamma$ R expression pattern is highly variable between different immune cells. NK cells, for example, only express the low affinity Fc $\gamma$ RIIIa receptor, while macrophages and monocytes express multiple receptors (Fc $\gamma$ RIa, IIa, $\mathrm{IIb}$, and IIIa) [26]. Depending on the Fc receptor a range of different effector functions can be triggered via the interaction with IgG, for example, binding of Fc $\gamma$ RIII a to IgG opsonized viruses or infected cells facilitates cross-linking of Fc $\gamma$ RIIIa, which initiates ADCC of the target cell.

Fc gamma receptors bind the Fc domain of IgG in a 1:1 stoichiometry via interactions with the lower hinge (residues 234-238), the CH2 domain (residues 265, 297, 298, 299, and 329), and the N297 Fc 
glycan [32]. All Fc $\gamma$ Rs bind to IgG via their second extracellular domain, which shows great structural homology between the $\mathrm{Fc}$ receptors (root mean square deviation of atomic positions $<1.0 \AA$ ). While all low-affinity receptors have two extracellular domains, the high-affinity receptor Fc $\gamma$ RIa consists of three domains. The interaction of antibodies with various Fc $\gamma$ Rs is influenced by the IgG subclass. IgG1 and IgG3 bind efficiently to all Fc gamma receptors, contributing to their overall strong effector function profile [28]. The affinity of IgG4 for Fc $\gamma$ RIa is two-fold lower compared to IgG1 and IgG3 $\left(\mathrm{K}_{\mathrm{A}} 3.4 \times 10^{7} \mathrm{M}^{-1}\right)$ [28]. IgG4 binds very weakly to the other Fc $\gamma$ Rs, which only leads to activation in situations where multivalency/avidity are involved [28]. IgG2 lacks a leucine at position 235 in the low hinge of $\mathrm{Fc}$ that is critical for binding to the high affinity receptor Fc $\gamma \mathrm{RIa}$. This may therefore be an important reason why IgG2 does not bind Fc $\gamma$ RIa [32]. Binding of IgG2 to Fc $\gamma$ RIIa and Fc $\gamma$ RIIIa is of low affinity ( $\mathrm{K}_{\mathrm{A}}$ of $10 \mathrm{e}^{6}$ and $10 \mathrm{e}^{5} \mathrm{M}^{-1}$, respectively), which is functionally relevant in the recognition of IgG2 immune complexes particularly through Fc $\gamma$ RIIa $[28,33]$. Of note, IgG2, which is almost exclusively found as fucosylated species in humans, does show elevated binding to Fc $\gamma$ RIIIa when afucosylated [33]. However, despite measurable binding to Fc $\gamma$ RIIIa, afucosylated IgG2 only showed a slight albeit not significant increase in ADCC by NK cells ( $<5 \%$ killing) using IgG2-anti-Rhesus D opsonized RBC [33].

Fc $\gamma \mathrm{R}$ are highly polymorphic, thus their exact composition differs from person to person, and the ethnic makeup is also variable [21]. Not all Fc $\gamma$ R-allotypic variation seems to have functional consequences, but a few polymorphisms are particularly noteworthy. Polymorphic variants of Fc $\gamma$ RIIa $(131 \mathrm{H} / \mathrm{R})$ and Fc $\gamma$ RIIIa (158F/V) have different binding affinities to IgG. Thus, in contrast to monomeric IgG1 and IgG3, IgG2 has a particularly strong preference for Fc $\gamma$ RIIa-131H compared to the Fc $\gamma$ RIIa-131R variant $[28,33]$. The polymorphic variant Fc $\gamma$ RIIIa $158 \mathrm{~V}$ binds IgG1 and IgG3 with a 5-fold stronger affinity compared to Fc $\gamma$ RIIIa 158F [33]. One allotypic variation results in the lack of expression of the FCGR2C gene, which is a pseudogene in most individuals and most ethnic groups [34]. However, in 7-15\% of individuals of European origin, Fc $\gamma$ RIIc (FCGR2C-ORF) is expressed on some immune cells, including NK cells and perhaps B cells [35-37]. Fc $\gamma$ RIIc expression depends on the presence of a single nucleotide polymorphism in exon 3 of FCGR2C, which normally encodes a stop codon (FCGR2C-Stop) [38]. Curiously, in some individuals with a FCGRIIC-STOP allele, Fc $\gamma$ RIIb expression has been found on NK cells, which is normally absent for this cell type. Although the reason is unknown, this phenotype is accompanied by a genetic deletion of the FCGR2C and FCGR3B genes adjacent to FCGR2B on one chromosome, perhaps because this results in a net replacement of the FCGR2B promotor with the promotor of FCGR2C [36].

In line with the differences in interaction with the IgG subclasses, Fc $\gamma \mathrm{R}$ polymorphisms were found to correlate with IgG-dependent diseases, such as in allo- and autoimmunity [39-41], and with outcome of treatment in therapeutic antibody regimens that trigger Fc $\gamma R$ for its therapeutic effect [21]. RA patients receiving rituximab treatment targeting CD20 on B cells generally respond better when bearing the higher-affinity Fc $\gamma$ RIIIa $158 \mathrm{~V}$ variant $[42,43]$. This advantage of expressing polymorphic variant Fc $\gamma$ RIIIa 158V was less conclusive in other patient groups receiving rituximab, for example patients with non-Hodgkin's lymphoma [44,45]. In addition to single nucleotide polymorphisms in the FCGR-gene locus that alter interaction with the IgG Fc domain, copy number variation (CNV) also influences Fc $\gamma$ R expression in a gene dosage fashion [36,46,47].

\subsection{DC-SIGN and CD23}

In addition to the type I Fc receptors that we discussed above, a second class of Fc receptors (type II) has been described to bind to the $\mathrm{CH} 2: \mathrm{CH} 3$ interface of sialylated IgG Fc [48,49]. These are the C-type lectin homologs DC-SIGN and CD23, of which the latter is the low-affinity receptor for $\mathrm{IgE}$, which has been proposed to embody another group of Fc engaging molecules. The sialylated Fc fraction of IVIG was proposed to be responsible for the anti-inflammatory mechanism of IVIG, through binding of these type II Fc receptors. Structural studies of sialylated Fc revealed that the overall conformation is comparable to nonsialylated $\mathrm{Fc}$, implying that the $\mathrm{CH} 2 \mathrm{CH} 3$ interface is not altered 
when the Fc-glycan is sialylated [50]. In fact, we and others found no detectable binding of human DC-SIGN and CD23 to human IgG Fc by FACS or SPR [51,52]. There is thus discrepancy between those reporting a biological effect of IgG through these receptors $[48,49,53,54]$ and those finding no effect $[50-52,55]$. However, the overall consensus seems now to indicate that DC-SIGN and CD23 are not bona fide receptors for human IgG.

\subsection{FcRn}

The neonatal $F_{C}$ receptor ( $\left.F_{C} R n\right)$ belongs to the family of MHC-related proteins and enables transcytosis of IgG over the maternal placenta. In addition, it mediates the long half-life of IgG. FcRn is rather ubiquitously expressed, including endothelial cells aligning our vessel walls, with a particularly high expression on myeloid cells [56]. Binding of IgG by FcRn occurs exclusively at low $\mathrm{pH}$ in endosomes $(\mathrm{pH}<6.5)$ after IgG is engulfed into endosomes via pinocytosis. Thereafter, FcRn shuttles IgG back to the cell membrane, where IgG dissociates from FcRn after fusion with the surface at a $\mathrm{pH}$ of 7.4 in the extracellular fluid. This $\mathrm{pH}$-dependent interaction results from the binding of FcRn with two histidines at the $\mathrm{CH} 2: \mathrm{CH} 3$ interface (H310 and $\mathrm{H} 435)$, which become protonated at low $\mathrm{pH}$ (pKa around 7.4) $[57,58]$. This property of the IgG-FcRn interaction is critical to allow for $\mathrm{pH}$-dependent FcRn-mediated shuttling of IgG. This increases the half-life of IgG1, IgG2, and IgG4 to 21 days. Most IgG3 allotypes lack the histidine at position 435, and instead have an arginine (pKa 12.5) at this position, which is always positively charged, independent of the physiological $\mathrm{pH}$ found in endosomes or extracellular medium. As a consequence, it is recycled to a much lesser extent than the other subclasses, and therefore has a much shorter half-life of $\sim 7$ days [59] and has less transport across the placenta $[60,61]$. However, some IgG3 allotypes express the histidine at position 435 (homologous to the other subclasses) and therefore have an increased half-life and transcytosis [59-61]. Interestingly, charge variations in the Fab domains of IgG have recently also been found to affect the half-life of IgG, suggesting that domains outside the binding site affect pinocytosis levels and/or in vivo FcRn binding kinetics $[62,63]$. In the proposed model, this effect may be due to the positively charged Fab domains affecting the interaction with the negatively charged cell membranes through the primary interaction site in the IgG-Fc.

\subsection{TRIM21}

Tripartite motif 21 (TRIM21) is an intracellular cytosolic IgG receptor which recognizes the $\mathrm{CH} 2 \mathrm{CH} 3$ interface, a binding site partly overlapping with that of FcRn. TRIM21 is a dimeric molecule, containing two PRYSPRY binding domains, which bind both $\mathrm{CH} 2 \mathrm{CH} 3$ elbow domains in a pincer-like interaction [25]. One PRYSPRY domain binds IgG with a reported affinity of 130nM [64,65]. However, the affinity of TRIM21 for IgG increases 250-fold when dimeric TRIM21 binds both IgG heavy chain $\mathrm{CH} 2: \mathrm{CH} 3$ domains simultaneously (reported affinity being $0.6 \mathrm{nM}$ ) [66]. A histidine at position 433 in the Fc domain of IgG is critical for binding of TRIM21 to the IgG Fc domain [67]. Entry of an IgG-opsonized non-enveloped virus or intracellular bacteria is recognized by TRIM21 and binding of TRIM21 triggers polyubiquitinylation of the opsonized particles and proteasomal degradation, as well as transcriptional activation of several immune regulator genes through the NF- $\mathrm{kB}, \mathrm{AP}-1$, and several IRF genes $[25,67,68]$. This process is described as antibody-dependent intracellular neutralization (ADIN), and extends the effector functions of antibodies to the intracellular compartment of cells. Whether strong immune signaling is initiated via activation of transcription factors, depends on the affinity of the antibody for the antigen/pathogen [67]. Viral particles opsonized with high affinity antibodies trigger transcriptional activation of immune regulators and production of cytokines [67]. So far, the evidence seem to suggest that early immune responses against cytosolic pathogens, probably non-enveloped viruses in particular, can be counteracted by the early immune response as TRIM21 also recognizes IgM and IgA [25]. Recognition of cytosolic immunoglobulins by TRIM21 may also function as a back-up mechanism in secondary infection for regular extracellular antibody mediated effector mechanisms when normal cellular compartmentalization has been compromised. 


\subsection{FcRL}

Fc receptor-like (FcRL) molecules are part of the immunoglobulin superfamily (IgSF). In the human context, six transmembrane receptors-FcRL1-6-are described, consisting of three to nine extracellular Ig-like domains and several ITIM and/or ITAM signaling molecules intracellularly. These receptors are expressed on $B$ cells, and the expression pattern of FcRLs varies during the different stages of B cell development [69]. In addition, FcRL3 and FcRL6 are also expressed on certain NK and T cell subsets [70-72]. The ligands of FCRL molecules and the processes in which signaling via FcRL is involved are not completely understood. However, FcRL4 (four extracellular immunoglobulin domains) and FcRL5 (eight extracellular immunoglobulins) were found to bind immunoglobulins with low affinity. FcRL4 specifically binds IgA, IgG3, and IgG4, while FcRL5 is able to bind all IgG subclasses $[73,74]$. The exact binding epitope of FcRL5 on IgG was not determined. However a complex binding interaction was proposed, in which both the Fc and Fab domains of IgG are involved in the interaction with FcRL5 [74]. Each receptor express several classical and atypical ITIM-motifs, as well as a potential ITAM-motif [75]. Both receptors are found on B cells suggesting a role in regulation of humoral immune responses [76]. One recent study suggested that FcRL5 can induce either inhibiting or activating signals to B cell receptor signaling pathways, depending on coligation with complement receptor 2 (CD21) [77]. This seems to suggest that complement C3 deposition may convert an inherent inhibitory signal to an activating signal and positively stimulate the humoral immune response. However, the exact mechanism and significance for human immune responses has not been elucidated.

\subsection{Complement ( $\mathrm{C} 1 q)$}

Binding of $\mathrm{C} 1 \mathrm{q}$ to monomeric $\operatorname{IgG}$ requires clustering of $\operatorname{IgG}$ to establish a multivalent interaction platform. This platform resembles that of an IgM molecule, which consists mostly of a pentameric structure, but can also form a hexameric structure, in the absence of a Joining $(\mathrm{J})$ chain, and binds $\mathrm{C} 1 \mathrm{q}$ in a 1:1 stoichiometry when bound to antigen $[1,78]$. Recently, it has been determined that IgG bound to a membrane structure is able to assume a hexameric configuration in complex with $\mathrm{C} 1$ thereby initiating complement activation. The structural characterization of an IgG1 hexamer in complex with C1q unraveled some important features of this interaction [79]. Two major interaction sites determine binding of the globular head domain of $\mathrm{C} 1 \mathrm{q}$ to IgG Fc. The BC loop (residues 266-272) and DE loop (294-300) of one CH2 domain are part of the first site and the FG loop (325-331) of the other $\mathrm{CH} 2$ domain is the second site [79]. Hexamer formation does not take place in solution to a measurable degree because the interactions between the individual IgG FC tails are very weak. However, upon binding a cellular surface, multiple antibodies are confined into a limited space, favoring Fc-Fc interactions between these IgG molecules, which is expected to be even more favorable in the presence of $\mathrm{C} 1 \mathrm{q}$. IgG hexamer formation is impaired when C-terminal lysines on IgG enforce charge repulsion between IgG molecules. The C-terminal clipping of these lysines residues by plasma carboxypeptidase is necessary to facilitate efficient hexamer formation and complement activation by IgG [80]. IgG is produced in a proform and C1q binding is also modulated by the glycoform of the N297 Fc glycan, with increasing galactosylation stimulating better $\mathrm{C} 1 \mathrm{q}$ binding and downstream activation (C3, C4 deposition, and CDC) [81-83]. Multivalent binding of IgG Fc condenses the C1q arms, which drives the rearrangements of the $\mathrm{C} 1 \mathrm{r} 2 \mathrm{~s} 2$ proteases allowing catalytic activity of these complement components [79]. In this particular structure an IgG1 hexamer was studied, although a structurally similar principle should apply to IgG3 despite its significantly longer hinge. Binding and activation of $\mathrm{C} 1 \mathrm{q}$ is in general believed to be more efficient with IgG3 compared to IgG1, although in certain cases CDC with IgG1 sometimes seems to outperform IgG3 [84-86]. The molecular reasons for this remain unresolved. 


\section{IgG Allotypes}

Similar to Fc $\gamma$ R, allotypic variations also exist for antibody heavy chains, especially for IgG. These polymorphisms form another layer of variation that may influence functional and structural features on top of what we know for the IgG subclasses [12]. Multiple studies found IgG polymorphisms to be associated with susceptibility to infectious diseases and autoimmune diseases, suggesting that IgG allotypes affect the humoral antibody response [87-92]. However, the structural or functional characteristics of $\operatorname{IgG}$ allotypes underlying these associations have not yet been elucidated.

The IgG allotypic background of an individual correlates with the individual IgG-subclass plasma levels $[93,94]$. A possible explanation may be the result of the formation of noncoding transcripts or RNA transcripts with unfavorable codon composition that impedes transcription and/or translation. In addition, IgG polymorphisms may also be associated with altered class switching efficiency, through variations within the noncoding switch regions, which would subsequently affect serum concentrations $[93,95,96]$. In a recent study, Shattock and colleagues showed that IgG1 allotypic variants were associated with the subclass distribution (IgG1/IgG2) of an HIV-specific antibody response, illustrating the association of IgG polymorphisms with the tendency for particular IgG subclass switching [97].

In addition to the association of IgG allotypes with antibody expression and IgG class switching in $\mathrm{B}$ cells, the Fc-mediated effector functions may be different between $\mathrm{IgG}$ allotypes. Previous studies already identified IgG3 allotypes with less stable CH3-CH3 interactions and an IgG4 allotype lacking the capacity to exchange half-molecules $[16,59,98,99]$. Furthermore, a particular IgG3 isoallotype (IMGT: IGHG3-17, -18, and -19) expressing a histidine at position 435 in the $\mathrm{CH} 3$ domain was found to improve $\mathrm{pH}$-dependent binding to the neonatal $\mathrm{F}_{\mathrm{C}}$ receptor $(\mathrm{FcRn})$ and therefore showed an half-life that resembled that of IgG1 antibodies [59]. Also, infants of mothers carrying this IgG3 polymorphic variant were found to have an increased protection against malaria, since the malaria specific IgG3 antibodies crossed the placental membrane more efficiently as a result of increased binding to FcRn $[60,61]$.

Future studies will shed light on the effector functions of the various IgG allotypes and the potential implications in susceptibility to infectious diseases or translation to antibody-based therapeutics. Interestingly, reactivity of monoclonal or polyclonal anti-IgG antibodies with all IgG allotypes indicated that some monoclonal antibodies, either subclass- or isotype-specific do not recognize all allotypic variants, a phenomenon described as 'serological blind spots' $[100,101]$. In addition, subclass-specific polyclonal anti-IgG were found to react with isoallotypic variants of another subclass, which could lead to misinterpretation of IgG subclass responses and can be of great importance, not only for scientific interpretations of immune responses, but also for critical diagnostic conclusion that leads to life-and-death decisions for patients [100].

\section{IgG Glycosylation}

Both heavy chains of the IgG express an N297-linked glycan in the CH2-domain in the Fc regions, which have a role in stability of the Fc domain and in the interaction with Fc $\gamma \mathrm{R}$ and possibly C1q [102]. During antibody production in the plasmablasts, the presence and activity of glycan-processing enzymes determines the composition of Fc-glycans, which results in a heterogeneous glycosylation pattern on antibodies.

Fucosylated complex glycans, with low-to-intermediate levels of galactosylation and low sialylation are most commonly found in serum IgG-Fc. Although not commonly found in plasma, afucosylated glycan-species of the N297 glycan (found in $\sim 6 \%$ of plasma IgG) were previously found to increase the binding strength of IgG-Fc to Fc $\gamma$ RIIIa $[81,103,104]$. This leads also to enhanced ADCC and has already been exploited in some therapeutic antibodies to improve their effector functions [105]. The molecular reason for the enhanced binding to the Fc $\gamma$ RIII-family of receptors has been enigmatic and has still not fully been uncovered, although it is known to depend on a glycan found at position 162 only in human Fc $\gamma$ RIII (a and b) (and conserved in other species, e.g., mice have F $\gamma$ RIV also with N162) [106]. Recent work based on structural modeling provided evidence that the number of 
conformations sampled by the N162-glycan is reduced by the presence of the fucose in the IgG Fc glycan $[107,108]$. This work suggests that the fucose moiety on the Fc glycan may be affecting the N162-glycan mobility which partially inhibits Fc $\gamma$ RIIIa/b to engage in binding. Thus, without the fucose, the IgG-glycan can more effectively make room for effective Fc $\gamma$ RIIIa/b binding. These notions are also supported by the fact that removing the N162 glycan of Fc $\gamma$ RIIIa also increases the affinity to IgG which is no longer affected by the fucosylation status of the IgG [106-109].

In recent years glycoengineering has been utilized to develop next generation afucosylated therapeutic antibodies with enhanced ADCC activity. For example, an afucosylated anti-CD20 antibody has been approved to treat patients with B cell lymphomas [105]. In addition to fucosylation, galactosylation and sialylation of the N297 glycan were also described to modulate IgG effector functions $[33,81-83,110]$. Whereas galactosylation of IgG seems to increase complement activation, sialylation has both been reported to decrease CDC activity of rituximab-IgG anti-CD20, but in other cases to increase RBC lysis of anti-D IgG1 [81,83]. As the architecture of the immune complex formed by the anti-CD20 and anti-D may differ, this may offer an explanation for the differential outcome [111]. Both studies were carried out using normal human serum as complement source (albeit at different concentrations $5 \%$ and $10 \%$ ). This may also offer a potential explanation as difference in serum composition (e.g., endogenous IgG glycosylation status and immune complex formation) may affect C1q binding to the intended target as we recently suggested [112].

Increased complement activation by IgG Fc galactosylation may also seem at odds with findings in several autoimmune diseases, where a low degree of galactosylation of total IgG-antibodies was found to be associated with disease progression [112]. Recently, we put forward a model that may explain how this is possible, taking into account the relative difference between the glycosylation of the pathogenic antibodies (in most cases not determined) and total IgG that may affect the threshold of immune activation [112]. This is because the bulk of aspecific IgG will always account for significant occupation of both Fc $\gamma \mathrm{R}$ but also partly C1q.

In addition to the conserved N-linked glycan in the Fc-domain [113], potential N-glycosylation sites are also present in the variable domain of antibodies. These Fab glycans have been described to modulate antibody stability, but also antigen binding directly $[114,115]$. As such, we recently postulated these sites to be a fundamental enhancement to the generation of antibody diversification - on top of VDJ recombination and somatic hypermutation leading to amino acid changes [114]. Fab glycosylation was found to be isotype and subclass-specific and associated with several autoimmune diseases including rheumatoid arthritis (RA) and primary Sjögren's syndrome [116-118]. Anticitrullinated protein antibodies (ACPA) are formed in the majority of RA patients and ACPA positive patients have an increased risk for rapid disease progression [119]. ACPA more frequently harbor Fab glycans compared to total serum IgG, suggesting that B cells producing auto-antibodies with Fab glycans are positively selected during affinity maturation [120]. In addition, the dominant Ig-producing cells in parotid glands of Primary Sjögren's syndrome were found to frequently express Fab glycans in the variable domain of the heavy chain [121]. In addition, it is possible that the existence of Fab-glycans may also affect regulation and affect the threshold for B cell activation through co-cross-linking of lectins in either cis or trans [122]. All in all, it is clear that both B cell biology, the humoral repertoire composition and the effector phase of antibodies is regulated through both Fab- and Fc-glycosylation.

\section{Antibody Fc engineering}

In recent years impressive progress has been made in the application of antibody-based therapeutics in various fields including B cell lymphomas, solid tumors and in autoimmune diseases. A popular strategy has been the generation of afucosylated antibody therapeutics to improve effector function of therapeutic antibodies for tumor immunotherapy. Both glycoengineering and protein engineering have rendered IgG FC domains with enhanced binding to activating $F_{C}$ receptors and reduced binding to inhibitory receptor Fc $\gamma$ RIIb [81,123-126]. 
When the primary mode of action of a therapeutic antibody is to block the activity of a molecule, such as a proinflammatory cytokine, antibodies lacking Fc-mediated effector functions, 'Fc dead', may be desired to prevent activation and inflammation during treatment [126]. This can sometimes partly be achieved by generating antibodies with an IgG4 Fc domain, IgG2 Fc domain, combination of both or an $\mathrm{N} 297$-glycan deficient $\mathrm{Fc}$ domain. Even better is to engineer IgG-Fc variants that have no Fc $\gamma \mathrm{R}$ or $\mathrm{C} 1 \mathrm{q}$ binding activity at all [127-129]. It should be cautioned that engineered antibodies may also express additional modes of action, e.g. afucosylated anti-TNF antibodies might have enhanced therapeutic potential in inflammatory bowel diseases. Although the exact mechanism is not known, it seems to require stimulation of wound healing macrophages through either TNF-anti-TNF- or membrane bound TNF-anti-TNF-complexes interacting with Fc $\gamma$ RIIIa on CD206+ macrophages [130].

Another strategy to improve the efficacy of therapeutic antibodies is based on enhancing the half-life of antibodies by increasing the affinity for FcRn at low pH. Structure-based design of Fc fragments with improved affinity for $\mathrm{FcRn}$ at low $\mathrm{pH}$ was found to increase the half-life of therapeutic antibodies in vivo [131-133]. To stimulate the clearance of harmful auto-antibodies, FcRn blocking antibodies or Fc-fragments have been developed. Most of these antibodies bind with increased affinity to $\mathrm{FcRn}$ and in an $\mathrm{pH}$ independent fashion, thereby blocking the receptor for recycling of serum IgG [134-136]. Alternatively anti-FcRn antibodies are designed to bind to FcRn at the interaction site with IgG, blocking IgG recycling [137,138].

In addition to the structural details that determine the interaction of IgG with Fc engaging effector molecules, the context in which these interactions occur are similarly important and very relevant for the implication of antibody-based therapeutics. For example antigen density and mobility on the cell surface of target cells determine whether the bound antibodies can sufficiently trigger Fc gamma receptor cross-linking, which is a prerequisite for ADCC and ADCP. Furthermore the distance of the antigen from the cellular surface was found to be important in the initiation of effector mechanism by antibodies $[139,140]$. Antigen positioned close to the membrane allows for a stronger interaction between effector cell and target cell, which drives a more efficient ADCC or ADCP [139].

Beyond tweaking the interaction between IgG and Fc engaging molecules, Fc engineering has also been extended to the generation of bispecific antibodies. This has been realized by swapping one half (e.g., one pair of a heavy and a light chain) of a specific IgG antibody with another half of an IgG molecule with a different specificity. This allows the resulting molecule to bind two different antigens simultaneously and gives bispecific antibodies several advantages. This has for example enabled the application for antibody therapeutics including dual epitope targeting and recruitment of $\mathrm{T}$ cells to targeted malignant cells. Two examples of strategies to produce bispecific antibodies are controlled Fab arm exchange (cFAE) and the knob-into-hole (KIH) design [141-143]. The latter strategy is based on the coexpression of two antibodies, one with a knob (bulky amino acid) and one with a hole in the $\mathrm{CH} 3 \mathrm{CH} 3$ interface. Coexpression of the knob and hole heavy chains with a common light chain followed by protA affinity chromatography leads to $95 \%$ heterodimerization efficiency [141,142]. The other strategy (cFAE) is also known as the DuoBody platform [143]. For each application of a bispecific antibody, whether that is cancer immunotherapy or neutralizing infectious agents, the desired features are different. This is why many different bispecific antibodies are developed based on full IgG (bsIgG) or single chain/variable domain only (scFv) [144,145].

In conclusion, antibodies come in all shapes and sizes and interact with a variety of ligands to mediate effector functions. For potential protection or therapeutic applications, the appropriate format that fits the target is likely to be of utmost importance. This is further complicated by the presence of regulatory inhibitory molecules/receptor-ligand pairs found in the immunological synapse regulating myeloid and NK cell activities [146]. For prophylactic immunotherapies with antibodies, there other factors that are important to consider. This may be especially in the tumor microenvironment where checkpoint receptor-ligand receptor pairs, which can be anti-inflammatory, must be overcome before therapeutic antibodies can be of beneficial value. This can be achieved by applying more potent engineered antibodies and/or by applying a combination of antibodies targeting both tumors and 
checkpoint inhibitors. This will affect both myeloid and lymphoid regulatory cells and secretion profiles stimulating or inhibiting cytokines [147,148]. The variety in antibodies in terms of isotype, allotype, subclass, glycosylation profile, and specificity, together with the number of Fc engaging molecules expressed on immune cells through which effector functions are exerted, illustrate the complexity and plasticity of the antibody response. Elucidating the interactions of antibodies with Fc engaging molecules is of crucial importance in the development of antibody therapeutics.

Author Contributions: S.W.d.T. wrote the paper and designed the figures, G.V. wrote and edited the paper, T.R. edited the paper.

Funding: This research received no external funding.

Conflicts of Interest: The authors declare no conflict of interest.

\section{References}

1. Hiramoto, E.; Tsutsumi, A.; Suzuki, R.; Matsuoka, S.; Arai, S.; Kikkawa, M.; Miyazaki, T. The IgM pentamer is an asymmetric pentagon with an open groove that binds the AIM protein. Sci. Adv. 2018, 4, eaau1199. [CrossRef]

2. Berkowska, M.A.; Driessen, G.J.A.; Bikos, V.; Grosserichter-Wagener, C.; Stamatopoulos, K.; Cerutti, A.; He, B.; Biermann, K.; Lange, J.F.; van der Burg, M.; et al. Human memory B cells originate from three distinct germinal center-dependent and -independent maturation pathways. Blood 2011, 118, 2150-2158. [CrossRef]

3. Methot, S.P.; Di Noia, J.M. Molecular Mechanisms of Somatic Hypermutation and Class Switch Recombination. Adv. Immunol. 2017, 133, 37-87. [PubMed]

4. Shan, M.; Carrillo, J.; Yeste, A.; Gutzeit, C.; Segura-Garzón, D.; Walland, A.C.; Pybus, M.; Grasset, E.K.; Yeiser, J.R.; Matthews, D.B.; et al. Secreted IgD Amplifies Humoral T Helper 2 Cell Responses by Binding Basophils via Galectin-9 and CD44. Immunity 2018, 49, 709-724. [CrossRef] [PubMed]

5. Gutzeit, C.; Chen, K.; Cerutti, A. The enigmatic function of IgD: some answers at last. Eur. J. Immunol. 2018, 48, 1101-1113. [CrossRef]

6. Horton, R.E.; Vidarsson, G. Antibodies and Their Receptors: Different Potential Roles in Mucosal Defense. Front. Immunol. 2013, 4, 200. [CrossRef] [PubMed]

7. Herr, A.B.; Ballister, E.R.; Bjorkman, P.J. Insights into IgA-mediated immune responses from the crystal structures of human Fc $\alpha$ RI and its complex with IgA1-Fc. Nature 2003, 423, 614-620. [CrossRef]

8. van Egmond, M.; van Garderen, E.; van Spriel, A.B.; Damen, C.A.; van Amersfoort, E.S.; van Zandbergen, G.; van Hattum, J.; Kuiper, J.; van de Winkel, J.G.J. Fc $\alpha$ RI-positive liver Kupffer cells: Reappraisal of the function of immunoglobulin A in immunity. Nat. Med. 2000, 6, 680-685. [CrossRef]

9. Vidarsson, G.; van Der Pol, W.L.; van Den Elsen, J.M.; Vilé, H.; Jansen, M.; Duijs, J.; Morton, H.C.; Boel, E.; Daha, M.R.; Corthésy, B.; et al. Activity of human IgG and IgA subclasses in immune defense against Neisseria meningitidis serogroup B. J. Immunol. 2001, 166, 6250-6256. [CrossRef] [PubMed]

10. Sutton, B.J.; Davies, A.M. Structure and dynamics of IgE-receptor interactions: FceRI and CD23/FceRII. Immunol. Rev. 2015, 268, 222-235. [CrossRef] [PubMed]

11. Bunker, J.J.; Bendelac, A. IgA Responses to Microbiota. Immunity 2018, 49, 211-224. [CrossRef] [PubMed]

12. Vidarsson, G.; Dekkers, G.; Rispens, T. IgG subclasses and allotypes: from structure to effector functions. Front. Immunol. 2014, 5, 520. [CrossRef] [PubMed]

13. Ferrante, A.; Beard, L.J.; Feldman, R.G. IgG subclass distribution of antibodies to bacterial and viral antigens. Pediatr. Infect. Dis. J. 1990, 9, 516-524. [CrossRef] [PubMed]

14. Lighaam, L.; Rispens, T. The Immunobiology of Immunoglobulin G4. Semin. Liver Dis. 2016, 36, $200-215$. [CrossRef] [PubMed]

15. van der Neut Kolfschoten, M.; Schuurman, J.; Losen, M.; Bleeker, W.K.; Martínez-Martínez, P.; Vermeulen, E.; den Bleker, T.H.; Wiegman, L.; Vink, T.; Aarden, L.A.; et al. Anti-inflammatory activity of immunoglobulin G resulting from Fc sialylation. Science 2007, 313, 670-673.

16. Rispens, T.; Davies, A.M.; Ooijevaar-de Heer, P.; Absalah, S.; Bende, O.; Sutton, B.J.; Vidarsson, G.; Aalberse, R.C. Dynamics of inter-heavy chain interactions in human immunoglobulin G (IgG) subclasses studied by kinetic Fab arm exchange. J. Biol. Chem. 2014, 289, 6098-6109. [CrossRef] 
17. Wypych, J.; Li, M.; Guo, A.; Zhang, Z.; Martinez, T.; Allen, M.J.; Fodor, S.; Kelner, D.N.; Flynn, G.C.; Liu, Y.D.; et al. Human IgG2 antibodies display disulfide-mediated structural isoforms. J. Biol. Chem. 2008, 283, 16194-16205. [CrossRef]

18. Barrett, D.J.; Ayoub, E.M. IgG2 subclass restriction of antibody to pneumococcal polysaccharides. Clin. Exp. Immunol. 1986, 63, 127-134.

19. Saeland, E.; Vidarsson, G.; Leusen, J.H.W.; Van Garderen, E.; Nahm, M.H.; Vile-Weekhout, H.; Walraven, V.; Stemerding, A.M.; Verbeek, J.S.; Rijkers, G.T.; et al. Central role of complement in passive protection by human IgG1 and IgG2 anti-pneumococcal antibodies in mice. J. Immunol. 2003, 170, 6158-6164. [CrossRef]

20. White, A.L.; Chan, H.T.C.; French, R.R.; Willoughby, J.; Mockridge, C.I.; Roghanian, A.; Penfold, C.A.; Booth, S.G.; Dodhy, A.; Polak, M.E.; et al. Conformation of the Human Immunoglobulin G2 Hinge Imparts Superagonistic Properties to Immunostimulatory Anticancer Antibodies. Cancer Cell 2015, 27, 138-148. [CrossRef]

21. Hargreaves, C.E.; Rose-Zerilli, M.J.J.; Machado, L.R.; Iriyama, C.; Hollox, E.J.; Cragg, M.S.; Strefford, J.C. Fc $\gamma$ receptors: genetic variation, function, and disease. Immunol. Rev. 2015, 268, 6-24. [CrossRef] [PubMed]

22. Li, F.J.; Won, W.J.; Becker, E.J.; Easlick, J.L.; Tabengwa, E.M.; Li, R.; Shakhmatov, M.; Honjo, K.; Burrows, P.D.; Davis, R.S. Emerging Roles for the FCRL Family Members in Lymphocyte Biology and Disease. In Curr. Top. Microbiol. Immunol. 2014, 382, 29-50.

23. Lu, J.; Kishore, U. C1 Complex: An Adaptable Proteolytic Module for Complement and Non-Complement Functions. Front. Immunol. 2017, 8, 592. [CrossRef] [PubMed]

24. Stapleton, N.M.; Einarsdóttir, H.K.; Stemerding, A.M.; Vidarsson, G. The multiple facets of FcRn in immunity. Immunol. Rev. 2015, 268, 253-268. [CrossRef]

25. Foss, S.; Watkinson, R.; Sandlie, I.; James, L.C.; Andersen, J.T. TRIM21: a cytosolic Fc receptor with broad antibody isotype specificity. Immunol. Rev. 2015, 268, 328-339. [CrossRef] [PubMed]

26. Gillis, C.; Gouel-Chéron, A.; Jönsson, F.; Bruhns, P. Contribution of Human Fc $\gamma$ Rs to Disease with Evidence from Human Polymorphisms and Transgenic Animal Studies. Front. Immunol. 2014, 5, 254. [CrossRef] [PubMed]

27. Daëron, M. F c RECEPTOR BIOLOGY. Annu. Rev. Immunol. 1997, 15, 203-234. [CrossRef]

28. Bruhns, P.; Iannascoli, B.; England, P.; Mancardi, D.A.; Fernandez, N.; Jorieux, S.; Daëron, M. Specificity and affinity of human Fcgamma receptors and their polymorphic variants for human IgG subclasses. Blood 2009, 113, 3716-3725. [CrossRef]

29. Vidarsson, G.; van de Winkel, J.G. Fc receptor and complement receptor-mediated phagocytosis in host defence. Curr. Opin. Infect. Dis. 1998, 11, 271-278. [CrossRef]

30. Veri, M.-C.; Gorlatov, S.; Li, H.; Burke, S.; Johnson, S.; Stavenhagen, J.; Stein, K.E.; Bonvini, E.; Koenig, S. Monoclonal antibodies capable of discriminating the human inhibitory Fc?-receptor IIB (CD32B) from the activating Fc?-receptor IIA (CD32A): biochemical, biological and functional characterization. Immunology 2007, 121, 392-404. [CrossRef]

31. Nimmerjahn, F.; Ravetch, J. V Divergent Immunoglobulin G Subclass Activity Through Selective Fc Receptor Binding. Science 2005, 310, 1510-1512. [CrossRef]

32. Caaveiro, J.M.M.; Kiyoshi, M.; Tsumoto, K. Structural analysis of Fc/Fc $\gamma$ R complexes: a blueprint for antibody design. Immunol. Rev. 2015, 268, 201-221. [CrossRef]

33. Bruggeman, C.W.; Dekkers, G.; Bentlage, A.E.H.; Treffers, L.W.; Nagelkerke, S.Q.; Lissenberg-Thunnissen, S.; Koeleman, C.A.M.; Wuhrer, M.; van den Berg, T.K.; Rispens, T.; et al. Enhanced effector functions due to antibody defucosylation depend on the effector cell Fc $\gamma$ receptor profile. J. Immunol. 2017, 199, $204-211$. [CrossRef]

34. Treffers, L.W.; van Houdt, M.; Bruggeman, C.W.; Heineke, M.H.; Zhao, X.W.; van der Heijden, J.; Nagelkerke, S.Q.; Verkuijlen, P.J.J.H.; Geissler, J.; Lissenberg-Thunnissen, S.; et al. Fc $\gamma$ RIIlb Restricts Antibody-Dependent Destruction of Cancer Cells by Human Neutrophils. Front. Immunol. 2019, 9, 3124. [CrossRef]

35. Meinderts, S.M.; Sins, J.W.R.; Fijnvandraat, K.; Nagelkerke, S.Q.; Geissler, J.; Tanck, M.W.; Bruggeman, C.; Biemond, B.J.; Rijneveld, A.W.; Kerkhoffs, J.-L.H.; et al. Nonclassical FCGR2C haplotype is associated with protection from red blood cell alloimmunization in sickle cell disease. Blood 2017, 130, 2121-2130. [CrossRef]

36. van der Heijden, J.; Breunis, W.B.; Geissler, J.; de Boer, M.; van den Berg, T.K.; Kuijpers, T.W. Phenotypic Variation in IgG Receptors by Nonclassical FCGR2C Alleles. J. Immunol. 2012, 188, 1318-1324. [CrossRef] 
37. Li, X.; Wu, J.; Ptacek, T.; Redden, D.T.; Brown, E.E.; Alarcón, G.S.; Ramsey-Goldman, R.; Petri, M.A.; Reveille, J.D.; Kaslow, R.A.; et al. Allelic-Dependent Expression of an Activating Fc Receptor on B Cells Enhances Humoral Immune Responses. Sci. Transl. Med. 2013, 5, 216ra175. [CrossRef]

38. Metes, D.; Ernst, L.K.; Chambers, W.H.; Sulica, A.; Herberman, R.B.; Morel, P.A. Expression of functional CD32 molecules on human NK cells is determined by an allelic polymorphism of the FcgammaRIIC gene. Blood 1998, 91, 2369-2380.

39. Breunis, W.B.; van Mirre, E.; Bruin, M.; Geissler, J.; de Boer, M.; Peters, M.; Roos, D.; de Haas, M.; Koene, H.R.; Kuijpers, T.W. Copy number variation of the activating FCGR2C gene predisposes to idiopathic thrombocytopenic purpura. Blood 2008, 111, 1029-1038. [CrossRef]

40. Stegmann, T.C.; Veldhuisen, B.; Nagelkerke, S.Q.; Winkelhorst, D.; Schonewille, H.; Verduin, E.P.; Kuijpers, T.W.; de Haas, M.; Vidarsson, G.; van der Schoot, C.E. RhIg-prophylaxis is not influenced by FCGR2/3 polymorphisms involved in red blood cell clearance. Blood 2017, 129, 1045-1048. [CrossRef]

41. Miescher, S.; Spycher, M.O.; Amstutz, H.; de Haas, M.; Kleijer, M.; Kalus, U.J.; Radtke, H.; Hubsch, A.; Andresen, I.; Martin, R.M.; et al. A single recombinant anti-RhD IgG prevents RhD immunization: association of RhD-positive red blood cell clearance rate with polymorphisms in the Fc $\gamma$ RIIA and Fc $\gamma$ IIIA genes. Blood 2004, 103, 4028-4035. [CrossRef]

42. Ruyssen-Witrand, A.; Rouanet, S.; Combe, B.; Dougados, M.; Le Loët, X.; Sibilia, J.; Tebib, J.; Mariette, X.; Constantin, A. Fc $\gamma$ receptor type IIIA polymorphism influences treatment outcomes in patients with rheumatoid arthritis treated with rituximab. Ann. Rheum. Dis. 2012, 71, 875-877. [CrossRef]

43. Lee, Y.H.; Bae, S.-C.; Song, G.G. Functional FCGR3A 158 V/F and IL-6 -174 C/G polymorphisms predict response to biologic therapy in patients with rheumatoid arthritis: a meta-analysis. Rheumatol. Int. 2014, 34, 1409-1415. [CrossRef]

44. Liu, D.; Tian, Y.; Sun, D.; Sun, H.; Jin, Y.; Dong, M. The FCGR3A polymorphism predicts the response to rituximab-based therapy in patients with non-Hodgkin lymphoma: a meta-analysis. Ann. Hematol. 2016, 95, 1483-1490. [CrossRef]

45. Carlotti, E.; Palumbo, G.A.; Oldani, E.; Tibullo, D.; Salmoiraghi, S.; Rossi, A.; Golay, J.; Pulsoni, A.; Foà, R.; Rambaldi, A. FcgammaRIIIA and FcgammaRIIA polymorphisms do not predict clinical outcome of follicular non-Hodgkin's lymphoma patients treated with sequential CHOP and rituximab. Haematologica 2007, 92, 1127-1130. [CrossRef]

46. van der Heijden, J.; Nagelkerke, S.; Zhao, X.; Geissler, J.; Rispens, T.; van den Berg, T.K.; Kuijpers, T.W. Haplotypes of Fc RIIa and Fc RIIIb Polymorphic Variants Influence IgG-Mediated Responses in Neutrophils. J. Immunol. 2014, 192, 2715-2721. [CrossRef]

47. Treffers, L.W.; Zhao, X.W.; van der Heijden, J.; Nagelkerke, S.Q.; van Rees, D.J.; Gonzalez, P.; Geissler, J.; Verkuijlen, P.; van Houdt, M.; de Boer, M.; et al. Genetic variation of human neutrophil Fc $\gamma$ receptors and $\mathrm{SIRP} \alpha$ in antibody-dependent cellular cytotoxicity towards cancer cells. Eur. J. Immunol. 2018, 48, 344-354. [CrossRef]

48. Sondermann, P.; Pincetic, A.; Maamary, J.; Lammens, K.; Ravetch, J.V. General mechanism for modulating immunoglobulin effector function. Proc. Natl. Acad. Sci. USA 2013, 110, 9868-9872. [CrossRef]

49. Anthony, R.M.; Wermeling, F.; Karlsson, M.C.I.; Ravetch, J.V. Identification of a receptor required for the anti-inflammatory activity of IVIG. Proc. Natl. Acad. Sci. USA 2008, 105, 19571-19578. [CrossRef]

50. Crispin, M.; Yu, X.; Bowden, T.A. Crystal structure of sialylated IgG Fc: Implications for the mechanism of intravenous immunoglobulin therapy. Proc. Natl. Acad. Sci. USA 2013, 110, E3544-E3546. [CrossRef]

51. Yu, X.; Vasiljevic, S.; Mitchell, D.A.; Crispin, M.; Scanlan, C.N. Dissecting the Molecular Mechanism of IVIg Therapy: The Interaction between Serum IgG and DC-SIGN is Independent of Antibody Glycoform or FC Domain. J. Mol. Biol. 2013, 425, 1253-1258. [CrossRef]

52. Temming, A.R.; Dekkers, G.; van de Bovenkamp, F.S.; Plomp, H.R.; Bentlage, A.E.H.; Szittner, Z.; Derksen, N.I.L.; Wuhrer, M.; Rispens, T.; Vidarsson, G. Human DC-SIGN and CD23 do not interact with human IgG. Submitted.

53. Anthony, R.M.; Wermeling, F.; Ravetch, J.V. Novel roles for the IgG Fc glycan. Ann. N. Y. Acad. Sci. 2012, 1253, 170-180. [CrossRef]

54. Ahmed, A.A.; Giddens, J.; Pincetic, A.; Lomino, J.V.; Ravetch, J.V.; Wang, L.-X.; Bjorkman, P.J. Structural Characterization of Anti-Inflammatory Immunoglobulin G Fc Proteins. J. Mol. Biol. 2014, 426, 3166-3179. [CrossRef] 
55. Guhr, T.; Bloem, J.; Derksen, N.I.L.; Wuhrer, M.; Koenderman, A.H.L.; Aalberse, R.C.; Rispens, T. Enrichment of sialylated $\mathrm{IgG}$ by lectin fractionation does not enhance the efficacy of immunoglobulin $\mathrm{G}$ in a murine model of immune thrombocytopenia. PLoS One 2011, 6, e21246. [CrossRef]

56. Vidarsson, G.; Stemerding, A.M.; Stapleton, N.M.; Spliethoff, S.E.; Janssen, H.; Rebers, F.E.; de Haas, M.; van de Winkel, J.G. FcRn: an IgG receptor on phagocytes with a novel role in phagocytosis. Blood 2006, 108, 3573-3579. [CrossRef]

57. Shimizu, A.; Honzawa, M.; Ito, S.; Miyazaki, T.; Matsumoto, H.; Nakamura, H.; Michaelsen, T.E.; Arata, Y. H NMR studies of the Fc region of human IgG1 and IgG3 immunoglobulins: assignment of histidine resonances in the $\mathrm{CH} 3$ domain and identification of IgG3 protein carrying G3m(st) allotypes. Mol. Immunol. 1983, 20, 141-148. [CrossRef]

58. Vaughn, D.E.; Bjorkman, P.J. Structural basis of pH-dependent antibody binding by the neonatal Fc receptor. Structure 1998, 6, 63-73. [CrossRef]

59. Stapleton, N.M.; Andersen, J.T.; Stemerding, A.M.; Bjarnarson, S.P.; Verheul, R.C.; Gerritsen, J.; Zhao, Y.; Kleijer, M.; Sandlie, I.; de Haas, M.; et al. Competition for FCRn-mediated transport gives rise to short half-life of human IgG3 and offers therapeutic potential. Nat. Commun. 2011, 2, 599. [CrossRef]

60. Einarsdottir, H.; Ji, Y.; Visser, R.; Mo, C.; Luo, G.; Scherjon, S.; van der Schoot, C.E.; Vidarsson, G. H435-containing immunoglobulin G3 allotypes are transported efficiently across the human placenta: implications for alloantibody-mediated diseases of the newborn. Transfusion 2014, 54, 665-671. [CrossRef]

61. Dechavanne, C.; Dechavanne, S.; Sadissou, I.; Lokossou, A.G.; Alvarado, F.; Dambrun, M.; Moutairou, K.; Courtin, D.; Nuel, G.; Garcia, A.; et al. Associations between an IgG3 polymorphism in the binding domain for FcRn, transplacental transfer of malaria-specific IgG3, and protection against Plasmodium falciparum malaria during infancy: A birth cohort study in Benin. PLoS Med. 2017, 14, e1002403. [CrossRef]

62. Schoch, A.; Kettenberger, H.; Mundigl, O.; Winter, G.; Engert, J.; Heinrich, J.; Emrich, T. Charge-mediated influence of the antibody variable domain on FcRn-dependent pharmacokinetics. Proc. Natl. Acad. Sci. USA 2015, 112, 5997-6002. [CrossRef]

63. Monnet, C.; Jorieux, S.; Urbain, R.; Fournier, N.; Bouayadi, K.; De Romeuf, C.; Behrens, C.K.; Fontayne, A.; Mondon, P. Selection of IgG Variants with Increased FcRn Binding Using Random and Directed Mutagenesis: Impact on Effector Functions. Front. Immunol. 2015, 6, 39. [CrossRef]

64. James, L.C.; Keeble, A.H.; Khan, Z.; Rhodes, D.A.; Trowsdale, J. Structural basis for PRYSPRY-mediated tripartite motif (TRIM) protein function. Proc. Natl. Acad. Sci. USA 2007, 104, 6200-6205. [CrossRef]

65. Keeble, A.H.; Khan, Z.; Forster, A.; James, L.C. TRIM21 is an IgG receptor that is structurally, thermodynamically, and kinetically conserved. Proc. Natl. Acad. Sci. USA 2008, 105, 6045-6050. [CrossRef]

66. Mallery, D.L.; McEwan, W.A.; Bidgood, S.R.; Towers, G.J.; Johnson, C.M.; James, L.C. Antibodies mediate intracellular immunity through tripartite motif-containing 21 (TRIM21). Proc. Natl. Acad. Sci. USA 2010, 107, 19985-19990. [CrossRef]

67. Foss, S.; Watkinson, R.E.; Grevys, A.; McAdam, M.B.; Bern, M.; Høydahl, L.S.; Dalhus, B.; Michaelsen, T.E.; Sandlie, I.; James, L.C.; et al. TRIM21 Immune Signaling Is More Sensitive to Antibody Affinity Than Its Neutralization Activity. J. Immunol. 2016, 196, 3452-3459. [CrossRef]

68. Fletcher, A.J.; Mallery, D.L.; Watkinson, R.E.; Dickson, C.F.; James, L.C. Sequential ubiquitination and deubiquitination enzymes synchronize the dual sensor and effector functions of TRIM21. Proc. Natl. Acad. Sci. USA 2015, 112, 10014-10019. [CrossRef]

69. Rostamzadeh, D.; Kazemi, T.; Amirghofran, Z.; Shabani, M. Update on Fc receptor-like (FCRL) family: new immunoregulatory players in health and diseases. Expert Opin. Ther. Targets 2018, 22, 487-502. [CrossRef]

70. Swainson, L.A.; Mold, J.E.; Bajpai, U.D.; McCune, J.M. Expression of the Autoimmune Susceptibility Gene FcRL3 on Human Regulatory T Cells Is Associated with Dysfunction and High Levels of Programmed Cell Death-1. J. Immunol. 2010, 184, 3639-3647. [CrossRef]

71. Bin Dhuban, K.; d'Hennezel, E.; Nashi, E.; Bar-Or, A.; Rieder, S.; Shevach, E.M.; Nagata, S.; Piccirillo, C.A. Coexpression of TIGIT and FCRL3 Identifies Helios ${ }^{+}$Human Memory Regulatory T Cells. J. Immunol. 2015, 194, 3687-3696. [CrossRef]

72. Kulemzin, S.V.; Zamoshnikova, A.Y.; Yurchenko, M.Y.; Vitak, N.Y.; Najakshin, A.M.; Fayngerts, S.A.; Chikaev, N.A.; Reshetnikova, E.S.; Kashirina, N.M.; Peclo, M.M.; et al. FCRL6 receptor: Expression and associated proteins. Immunol. Lett. 2011, 134, 174-182. [CrossRef] 
73. Wilson, T.J.; Fuchs, A.; Colonna, M. Cutting Edge: Human FcRL4 and FcRL5 Are Receptors for IgA and IgG. J. Immunol. 2012, 188, 4741-4745. [CrossRef]

74. Franco, A.; Damdinsuren, B.; Ise, T.; Dement-Brown, J.; Li, H.; Nagata, S.; Tolnay, M. Human Fc receptor-like 5 binds intact IgG via mechanisms distinct from those of FC receptors. J. Immunol. 2013, 190, 5739-5746. [CrossRef]

75. Miller, I.; Hatzivassiliou, G.; Cattoretti, G.; Mendelsohn, C.; Dalla-Favera, R. IRTAs: a new family of immunoglobulinlike receptors differentially expressed in B cells. Blood 2002, 99, 2662-2669. [CrossRef]

76. Haga, C.L.; Ehrhardt, G.R.A.; Boohaker, R.J.; Davis, R.S.; Cooper, M.D. Fc receptor-like 5 inhibits B cell activation via SHP-1 tyrosine phosphatase recruitment. Proc. Natl. Acad. Sci. USA 2007, 104, 9770-9775. [CrossRef]

77. Franco, A.; Kraus, Z.; Li, H.; Seibert, N.; Dement-Brown, J.; Tolnay, M. CD21 and FCRL5 form a receptor complex with robust B-cell activating capacity. Int. Immunol. 2018, 30, 569-578. [CrossRef]

78. Niles, M.J.; Matsuuchi, L.; Koshland, M.E. Polymer IgM assembly and secretion in lymphoid and nonlymphoid cell lines: evidence that J chain is required for pentamer IgM synthesis. Proc. Natl. Acad. Sci. USA 1995, 92, 2884-2888. [CrossRef]

79. Ugurlar, D.; Howes, S.C.; de Kreuk, B.-J.; Koning, R.I.; de Jong, R.N.; Beurskens, F.J.; Schuurman, J.; Koster, A.J.; Sharp, T.H.; Parren, P.W.H.I.; et al. Structures of C1-IgG1 provide insights into how danger pattern recognition activates complement. Science 2018, 359, 794-797. [CrossRef]

80. van den Bremer, E.T.; Beurskens, F.J.; Voorhorst, M.; Engelberts, P.J.; de Jong, R.N.; van der Boom, B.G.; Cook, E.M.; Lindorfer, M.A.; Taylor, R.P.; van Berkel, P.H.; et al. Human IgG is produced in a pro-form that requires clipping of C-terminal lysines for maximal complement activation. MAbs 2015, 7, 672-680. [CrossRef]

81. Dekkers, G.; Treffers, L.; Plomp, R.; Bentlage, A.E.H.; de Boer, M.; Koeleman, C.A.M.; Lissenberg-Thunnissen, S.N.; Visser, R.; Brouwer, M.; Mok, J.Y.; et al. Decoding the human immunoglobulin G-glycan repertoire reveals a spectrum of Fc-receptor- and complement-mediated-effector activities. Front. Immunol. 2017, 8. [CrossRef]

82. Quast, I.; Keller, C.W.; Maurer, M.A.; Giddens, J.P.; Tackenberg, B.; Wang, L.-X.; Münz, C.; Nimmerjahn, F.; Dalakas, M.C.; Lünemann, J.D. Sialylation of IgG Fc domain impairs complement-dependent cytotoxicity. J. Clin. Invest. 2015, 125, 4160-4170. [CrossRef]

83. Peschke, B.; Keller, C.W.; Weber, P.; Quast, I.; Lünemann, J.D. Fc-Galactosylation of Human Immunoglobulin Gamma Isotypes Improves C1q Binding and Enhances Complement-Dependent Cytotoxicity. Front. Immunol. 2017, 8, 646. [CrossRef]

84. Brüggemann, M.; Williams, G.T.; Bindon, C.I.; Clark, M.R.; Walker, M.R.; Jefferis, R.; Waldmann, H.; Neuberger, M.S. Comparison of the effector functions of human immunoglobulins using a matched set of chimeric antibodies. J. Exp. Med. 1987, 166, 1351-1361. [CrossRef]

85. Natsume, A.; In, M.; Takamura, H.; Nakagawa, T.; Shimizu, Y.; Kitajima, K.; Wakitani, M.; Ohta, S.; Satoh, M.; Shitara, K.; et al. Engineered antibodies of IgG1/IgG3 mixed isotype with enhanced cytotoxic activities. Cancer Res. 2008, 68, 3863-3872. [CrossRef]

86. Giuntini, S.; Granoff, D.M.; Beernink, P.T.; Ihle, O.; Bratlie, D.; Michaelsen, T.E. Human IgG1, IgG3, and IgG3 Hinge-Truncated Mutants Show Different Protection Capabilities against Meningococci Depending on the Target Antigen and Epitope Specificity. Clin. Vaccine Immunol. 2016, 23, 698-706. [CrossRef]

87. Oxelius, V.-A.; Pandey, J.P. Human immunoglobulin constant heavy G chain (IGHG) (Fc $\gamma$ ) (GM) genes, defining innate variants of IgG molecules and B cells, have impact on disease and therapy. Clin. Immunol. 2013, 149, 475-486. [CrossRef]

88. Oxelius, V.-A. Immunoglobulin constant heavy G subclass chain genes in asthma and allergy. Immunol. Res. 2008, 40, 179-191. [CrossRef]

89. Oxelius, V.A.; Carlsson, A.M.; Aurivillius, M. Alternative G1m, G2m and G3m allotypes of IGHG genes correlate with atopic and nonatopic pathways of immune regulation in children with bronchial asthma. Int. Arch. Allergy Immunol. 1998, 115, 215-219. [CrossRef]

90. O’Hanlon, T.P.; Rider, L.G.; Schiffenbauer, A.; Targoff, I.N.; Malley, K.; Pandey, J.P.; Miller, F.W. Immunoglobulin gene polymorphisms are susceptibility factors in clinical and autoantibody subgroups of the idiopathic inflammatory myopathies. Arthritis Rheum. 2008, 58, 3239-3246. [CrossRef]

91. Pandey, J.P.; Namboodiri, A.M. Genetic variants of IgG1 antibodies and Fc $\gamma$ RIIIa receptors influence the magnitude of antibody-dependent cell-mediated cytotoxicity against prostate cancer cells. Oncoimmunology 2014, 3, e27317. [CrossRef] 
92. Pandey, J.P.; Luo, Y.; Elston, R.C.; Wu, Y.; Philp, F.H.; Astemborski, J.; Thomas, D.L.; Netski, D.M. Immunoglobulin allotypes influence IgG antibody responses to hepatitis $\mathrm{C}$ virus envelope proteins $\mathrm{E} 1$ and E2. Hum. Immunol. 2008, 69, 158-164. [CrossRef]

93. Seppälä, I.J.; Sarvas, H.; Mäkelä, O. Low concentrations of Gm allotypic subsets G3 mg and G1 mf in homozygotes and heterozygotes. J. Immunol. 1993, 151, 2529-2537.

94. Pan, Q.; Petit-Frére, C.; Hammarström, L. An allotype-associated polymorphism in the $\gamma 3$ promoter determines the germ-line $\gamma 3$ transcriptional rate but does not influence switching and subsequent IgG3 production. Eur. J. Immunol. 2000, 30, 2388-2393. [CrossRef]

95. Jonsson, S.; Sveinbjornsson, G.; de Lapuente Portilla, A.L.; Swaminathan, B.; Plomp, R.; Dekkers, G.; Ajore, R.; Ali, M.; Bentlage, A.E.H.; Elmér, E.; et al. Identification of sequence variants influencing immunoglobulin levels. Nat. Genet. 2017, 49, 1182-1191. [CrossRef]

96. Pan, Q.; Hammarström, L. Molecular basis of IgG subclass deficiency. Immunol. Rev. 2000, 178, 99-110. [CrossRef]

97. Kratochvil, S.; McKay, P.F.; Chung, A.W.; Kent, S.J.; Gilmore, J.; Shattock, R.J. Immunoglobulin G1 allotype influences antibody subclass distribution in response to HIV gp140 vaccination. Front. Immunol. 2017, 8, 1883. [CrossRef]

98. Ternant, D.; Arnoult, C.; Pugnière, M.; Dhommée, C.; Drocourt, D.; Perouzel, E.; Passot, C.; Baroukh, N.; Mulleman, D.; Tiraby, G.; et al. IgG1 Allotypes Influence the Pharmacokinetics of Therapeutic Monoclonal Antibodies through FcRn Binding. J. Immunol. 2016, 196, 607-613. [CrossRef]

99. Brusco, A.; Saviozzi, S.; Cinque, F.; DeMarchi, M.; Boccazzi, C.; de Lange, G.; van Leeuwen, A.M.; Carbonara, A.O. Molecular characterization of immunoglobulin G4 gene isoallotypes. Eur. J. Immunogenet. 1998, 25, 349-355. [CrossRef]

100. Howie, H.L.; Delaney, M.; Wang, X.; Er, L.S.; Kapp, L.; Lebedev, J.N.; Zimring, J.C. Errors in data interpretation from genetic variation of human analytes. JCI Insight 2017, 2, 1-9. [CrossRef]

101. Howie, H.L.; Delaney, M.; Wang, X.; Er, L.S.; Vidarsson, G.; Stegmann, T.C.; Kapp, L.; Lebedev, J.N.; Wu, Y.; AuBuchon, J.P.; et al. Serological blind spots for variants of human IgG3 and IgG4 by a commonly used anti-immunoglobulin reagent. Transfusion 2016, 56, 2953-2962. [CrossRef]

102. Subedi, G.P.; Barb, A.W. The Structural Role of Antibody N-Glycosylation in Receptor Interactions. Structure 2015, 23, 1573-1583. [CrossRef] [PubMed]

103. Niwa, R.; Natsume, A.; Uehara, A.; Wakitani, M.; Iida, S.; Uchida, K.; Satoh, M.; Shitara, K. IgG subclass-independent improvement of antibody-dependent cellular cytotoxicity by fucose removal from Asn297-linked oligosaccharides. J. Immunol. Methods 2005, 306, 151-160. [CrossRef] [PubMed]

104. Shinkawa, T.; Nakamura, K.; Yamane, N.; Shoji-Hosaka, E.; Kanda, Y.; Sakurada, M.; Uchida, K.; Anazawa, H.; Satoh, M.; Yamasaki, M.; et al. The Absence of Fucose but Not the Presence of Galactose or Bisecting N -Acetylglucosamine of Human IgG1 Complex-type Oligosaccharides Shows the Critical Role of Enhancing Antibody-dependent Cellular Cytotoxicity. J. Biol. Chem. 2003, 278, 3466-3473. [CrossRef] [PubMed]

105. Pereira, N.A.; Chan, K.F.; Lin, P.C.; Song, Z. The "less-is-more" in therapeutic antibodies: Afucosylated anti-cancer antibodies with enhanced antibody-dependent cellular cytotoxicity. MAbs 2018, 10, 693-711. [CrossRef]

106. Dekkers, G.; Bentlage, A.E.H.; Plomp, R.; Visser, R.; Koeleman, C.A.M.; Beentjes, A.; Mok, J.Y.; van Esch, W.J.E.; Wuhrer, M.; Rispens, T.; et al. Conserved Fc $\gamma$ R- glycan discriminates between fucosylated and afucosylated IgG in humans and mice. Mol. Immunol. 2018, 94, 54-60. [CrossRef] [PubMed]

107. Patel, K.R.; Roberts, J.T.; Subedi, G.P.; Barb, A.W. Restricted processing of CD16a/Fc receptor IIIa N-glycans from primary human NK cells impacts structure and function. J. Biol. Chem. 2018, 293, 3477-3489. [CrossRef]

108. Falconer, D.J.; Subedi, G.P.; Marcella, A.M.; Barb, A.W. Antibody fucosylation lowers the Fc $\gamma$ RIIIa/CD16a affinity by limiting the conformations sampled by the N162-glycan. ACS Chem. Biol. 2018, 13, 2179-2189. [CrossRef]

109. Ferrara, C.; Grau, S.; Jäger, C.; Sondermann, P.; Brünker, P.; Waldhauer, I.; Hennig, M.; Ruf, A.; Rufer, A.C.; Stihle, M.; et al. Unique carbohydrate-carbohydrate interactions are required for high affinity binding between FcgammaRIII and antibodies lacking core fucose. Proc. Natl. Acad. Sci. USA 2011, 108, 12669-12674. [CrossRef]

110. Thomann, M.; Reckermann, K.; Reusch, D.; Prasser, J.; Tejada, M.L. Fc-galactosylation modulates antibody-dependent cellular cytotoxicity of therapeutic antibodies. Mol. Immunol. 2016, 73, 69-75. [CrossRef] 
111. Beers, S.A.; Chan, C.H.T.; French, R.R.; Cragg, M.S.; Glennie, M.J. CD20 as a Target for Therapeutic Type I and II Monoclonal Antibodies. Semin. Hematol. 2010, 47, 107-114. [CrossRef]

112. Dekkers, G.; Rispens, T.; Vidarsson, G. Novel Concepts of Altered Immunoglobulin G Galactosylation in Autoimmune Diseases. Front. Immunol. 2018, 9, 553. [CrossRef]

113. Pincetic, A.; Bournazos, S.; DiLillo, D.J.; Maamary, J.; Wang, T.T.; Dahan, R.; Fiebiger, B.-M.; Ravetch, J. V Type I and type II Fc receptors regulate innate and adaptive immunity. Nat. Immunol. 2014, 15, 707-716. [CrossRef]

114. van de Bovenkamp, F.S.; Derksen, N.I.L.; Ooijevaar-de Heer, P.; van Schie, K.A.; Kruithof, S.; Berkowska, M.A.; van der Schoot, C.E.; IJspeert, H.; van der Burg, M.; Gils, A.; et al. Adaptive antibody diversification through $N$-linked glycosylation of the immunoglobulin variable region. Proc. Natl. Acad. Sci. USA 2018, 115, 1901-1906. [CrossRef]

115. van de Bovenkamp, F.S.; Derksen, N.I.L.; van Breemen, M.J.; de Taeye, S.W.; Ooijevaar-de Heer, P.; Sanders, R.W.; Rispens, T. Variable Domain N-Linked Glycans Acquired During Antigen-Specific Immune Responses Can Contribute to Immunoglobulin G Antibody Stability. Front. Immunol. 2018, 9, 740. [CrossRef]

116. Hamza, N.; Hershberg, U.; Kallenberg, C.G.M.; Vissink, A.; Spijkervet, F.K.L.; Bootsma, H.; Kroese, F.G.M.; Bos, N.A. Ig Gene Analysis Reveals Altered Selective Pressures on Ig-Producing Cells in Parotid Glands of Primary Sjögren's Syndrome Patients. J. Immunol. 2015, 194, 514-521. [CrossRef]

117. Youings, A.; Chang, S.C.; Dwek, R.A.; Scragg, I.G. Site-specific glycosylation of human immunoglobulin G is altered in four rheumatoid arthritis patients. Biochem. J. 1996, 314, 621-630. [CrossRef]

118. Koers, J.; Derksen, N.I.L.; Ooijevaar-de Heer, P.; Nota, B.; van de Bovenkamp, F.S.; Vidarsson, G.; Rispens, T. Biased N-Glycosylation Site Distribution and Acquisition across the Antibody V Region during B Cell Maturation. J. Immunol. 2019, 202, 2220-2228. [CrossRef]

119. Willemze, A.; Trouw, L.A.; Toes, R.E.M.; Huizinga, T.W.J. The influence of ACPA status and characteristics on the course of RA. Nat. Rev. Rheumatol. 2012, 8, 144-152. [CrossRef]

120. Rombouts, Y.; Willemze, A.; van Beers, J.J.B.C.; Shi, J.; Kerkman, P.F.; van Toorn, L.; Janssen, G.M.C.; Zaldumbide, A.; Hoeben, R.C.; Pruijn, G.J.M.; et al. Extensive glycosylation of ACPA-IgG variable domains modulates binding to citrullinated antigens in rheumatoid arthritis. Ann. Rheum. Dis. 2016, 75, 578-585. [CrossRef]

121. Visser, A.; Doorenspleet, M.E.; de Vries, N.; Spijkervet, F.K.L.; Vissink, A.; Bende, R.J.; Bootsma, H.; Kroese, F.G.M.; Bos, N.A. Acquisition of N-Glycosylation Sites in Immunoglobulin Heavy Chain Genes During Local Expansion in Parotid Salivary Glands of Primary Sjögren Patients. Front. Immunol. 2018, 9, 491. [CrossRef]

122. van de Bovenkamp, F.S.; Hafkenscheid, L.; Rispens, T.; Rombouts, Y. The Emerging Importance of IgG Fab Glycosylation in Immunity. J. Immunol. 2016, 196. [CrossRef]

123. Stavenhagen, J.B.; Gorlatov, S.; Tuaillon, N.; Rankin, C.T.; Li, H.; Burke, S.; Huang, L.; Vijh, S.; Johnson, S.; Bonvini, E.; et al. Fc optimization of therapeutic antibodies enhances their ability to kill tumor cells in vitro and controls tumor expansion in vivo via low-affinity activating Fcgamma receptors. Cancer Res. 2007, 67, 8882-8890. [CrossRef]

124. Nordstrom, J.L.; Gorlatov, S.; Zhang, W.; Yang, Y.; Huang, L.; Burke, S.; Li, H.; Ciccarone, V.; Zhang, T.; Stavenhagen, J.; et al. Anti-tumor activity and toxicokinetics analysis of MGAH22, an anti-HER2 monoclonal antibody with enhanced Fc $\gamma$ receptor binding properties. Breast Cancer Res. 2011, 13, R123. [CrossRef]

125. Romain, G.; Senyukov, V.; Rey-Villamizar, N.; Merouane, A.; Kelton, W.; Liadi, I.; Mahendra, A.; Charab, W.; Georgiou, G.; Roysam, B.; et al. Antibody Fc engineering improves frequency and promotes kinetic boosting of serial killing mediated by NK cells. Blood 2014, 124, 3241-3249. [CrossRef]

126. Bruhns, P.; Jönsson, F. Mouse and human FcR effector functions. Immunol. Rev. 2015, 268, 25-51. [CrossRef]

127. Vafa, O.; Gilliland, G.L.; Brezski, R.J.; Strake, B.; Wilkinson, T.; Lacy, E.R.; Scallon, B.; Teplyakov, A.; Malia, T.J.; Strohl, W.R. An engineered Fc variant of an IgG eliminates all immune effector functions via structural perturbations. Methods 2014, 65, 114-126. [CrossRef]

128. An, Z.; Forrest, G.; Moore, R.; Cukan, M.; Haytko, P.; Huang, L.; Vitelli, S.; Zhao, J.Z.; Lu, P.; Hua, J.; et al. IgG2m4, an engineered antibody isotype with reduced Fc function. MAbs 2009, 1, 572-579. [CrossRef]

129. Stapleton, N.M.; Armstrong-Fisher, S.S.; Andersen, J.T.; van der Schoot, C.E.; Porter, C.; Page, K.R.; Falconer, D.; de Haas, M.; Williamson, L.M.; Clark, M.R.; et al. Human IgG lacking effector functions demonstrate lower FcRn-binding and reduced transplacental transport. Mol. Immunol. 2018, 95, 1-9. [CrossRef] 
130. Bloemendaal, F.M.; Levin, A.D.; Wildenberg, M.E.; Koelink, P.J.; McRae, B.L.; Salfeld, J.; Lum, J.; van der Neut Kolfschoten, M.; Claassens, J.W.; Visser, R.; et al. Anti-Tumor Necrosis Factor With a Glyco-Engineered Fc-Region Has Increased Efficacy in Mice With Colitis. Gastroenterology 2017, 153, 1351-1362.e4. [CrossRef]

131. Zalevsky, J.; Chamberlain, A.K.; Horton, H.M.; Karki, S.; Leung, I.W.L.; Sproule, T.J.; Lazar, G.A.; Roopenian, D.C.; Desjarlais, J.R. Enhanced antibody half-life improves in vivo activity. Nat. Biotechnol. 2010, 28, 157-159. [CrossRef]

132. Monnet, C.; Jorieux, S.; Souyris, N.; Zaki, O.; Jacquet, A.; Fournier, N.; Crozet, F.; de Romeuf, C.; Bouayadi, K.; Urbain, R.; et al. Combined glyco- and protein-Fc engineering simultaneously enhance cytotoxicity and half-life of a therapeutic antibody. MAbs 2014, 6, 422-436. [CrossRef]

133. Dall'Acqua, W.F.; Kiener, P.A.; Wu, H. Properties of Human IgG1s Engineered for Enhanced Binding to the Neonatal Fc Receptor (FcRn). J. Biol. Chem. 2006, 281, 23514-23524. [CrossRef]

134. Patel, D.A.; Puig-Canto, A.; Challa, D.K.; Montoyo, H.P.; Ober, R.J.; Ward, E.S. Neonatal Fc Receptor Blockade by Fc Engineering Ameliorates Arthritis in a Murine Model. J. Immunol. 2011, 187, 1015-1022. [CrossRef]

135. Ling, L.E.; Hillson, J.L.; Tiessen, R.G.; Bosje, T.; Iersel, M.P.; Nix, D.J.; Markowitz, L.; Cilfone, N.A.; Duffner, J.; Streisand, J.B.; et al. M281, an Anti-FcRn Antibody: Pharmacodynamics, Pharmacokinetics, and Safety Across the Full Range of IgG Reduction in a First-in-Human Study. Clin. Pharmacol. Ther. 2019, 105, 1031-1039. [CrossRef]

136. Kiessling, P.; Lledo-Garcia, R.; Watanabe, S.; Langdon, G.; Tran, D.; Bari, M.; Christodoulou, L.; Jones, E.; Price, G.; Smith, B.; et al. The FcRn inhibitor rozanolixizumab reduces human serum IgG concentration: A randomized phase 1 study. Sci. Transl. Med. 2017, 9, eaan1208. [CrossRef]

137. Ward, E.S.; Ober, R.J. Targeting FcRn to Generate Antibody-Based Therapeutics. Trends Pharmacol. Sci. 2018, 39, 892-904. [CrossRef]

138. Ulrichts, P.; Guglietta, A.; Dreier, T.; van Bragt, T.; Hanssens, V.; Hofman, E.; Vankerckhoven, B.; Verheesen, P.; Ongenae, N.; Lykhopiy, V.; et al. Neonatal Fc receptor antagonist efgartigimod safely and sustainably reduces IgGs in humans. J. Clin. Investig. 2018, 128, 4372-4386. [CrossRef]

139. Cleary, K.L.S.; Chan, H.T.C.; James, S.; Glennie, M.J.; Cragg, M.S. Antibody distance from the cell membrane regulates antibody effector mechanisms. J. Immunol. 2017, 198, 3999-4011. [CrossRef]

140. Rösner, T.; Derer, S.; Kellner, C.; Dechant, M.; Lohse, S.; Vidarsson, G.; Peipp, M.; Valerius, T. An IgG3 switch variant of rituximab mediates enhanced complement-dependent cytotoxicity against tumour cells with low CD20 expression levels. Br. J. Haematol. 2013, 161, 282-286. [CrossRef]

141. Carter, P. Bispecific human IgG by design. J. Immunol. Methods 2001, 248, 7-15. [CrossRef]

142. Merchant, A.M.; Zhu, Z.; Yuan, J.Q.; Goddard, A.; Adams, C.W.; Presta, L.G.; Carter, P. An efficient route to human bispecific IgG. Nat. Biotechnol. 1998, 16, 677-681. [CrossRef]

143. Labrijn, A.F.; Meesters, J.I.; de Goeij, B.E.C.G.; van den Bremer, E.T.J.; Neijssen, J.; van Kampen, M.D.; Strumane, K.; Verploegen, S.; Kundu, A.; Gramer, M.J.; et al. Efficient generation of stable bispecific IgG1 by controlled Fab-arm exchange. Proc. Natl. Acad. Sci. USA 2013, 110, 5145-5150. [CrossRef]

144. Brinkmann, U.; Kontermann, R.E. The making of bispecific antibodies. MAbs 2017, 9, 182-212. [CrossRef]

145. Sedykh, S.E.; Prinz, V.V.; Buneva, V.N.; Nevinsky, G.A. Bispecific antibodies: design, therapy, perspectives. Drug Des. Devel. Ther. 2018, 12, 195. [CrossRef]

146. Bakalar, M.H.; Joffe, A.M.; Schmid, E.M.; Son, S.; Podolski, M.; Fletcher, D.A. Size-dependent segregation controls macrophage phagocytosis of antibody-opsonized targets. Cell 2018, 174, 131-142. [CrossRef]

147. Bohn, T.; Rapp, S.; Luther, N.; Klein, M.; Bruehl, T.-J.; Kojima, N.; Aranda Lopez, P.; Hahlbrock, J.; Muth, S.; Endo, S.; et al. Tumor immunoevasion via acidosis-dependent induction of regulatory tumor-associated macrophages. Nat. Immunol. 2018, 19, 1319-1329. [CrossRef]

148. Li, H.Y.; McSharry, M.; Bullock, B.; Nguyen, T.T.; Kwak, J.; Poczobutt, J.M.; Sippel, T.R.; Heasley, L.E.; Weiser-Evans, M.C.; Clambey, E.T.; et al. The Tumor Microenvironment Regulates Sensitivity of Murine Lung Tumors to PD-1/PD-L1 Antibody Blockade. Cancer Immunol. Res. 2017, 5, 767-777. [CrossRef]

(C) 2019 by the authors. Licensee MDPI, Basel, Switzerland. This article is an open access article distributed under the terms and conditions of the Creative Commons Attribution (CC BY) license (http://creativecommons.org/licenses/by/4.0/). 